\title{
CORPORATE SOCIAL RESPONSIBILITY DAN TANGGUNG JAWAB NEGARA TERHADAP HAK EKONOMI, SOSIAL, DAN BUDAYA DI INDONESIA
}

\author{
Sefriani, Sri Wartini \\ Fakultas Hukum Universitas Islam Indoneia \\ Email : sefri_ani@yahoo.com; sri.wartini67@yahoo.com
}

\begin{abstract}
Indonesia has enacted the idea of corporate social responsibility (CSR) into the laws as a liability which bears sanctions. It is uncommon practice. The majority of state's practices are putting CSR as a voluntary issue on the law instead of treating it as a liability which holds sanctions. Such enactment give rise allegation against the state which accusing it for transferring its obligation to fulfill the economic, social and culture rights (ESCR) to the company in the format of CSR. Indonesia has some arguments to justify such enactment such as 75\% environmental destruction and social problems in Indonesia caused by company activities; the company is able to violate human rights even worse than other legal subject can do; the law which possess voluntary characteristic was ineffective in Indonesia since the legal culture and the awareness concerning the importance of CSR is still not quite; provide legal certainty and avoid inconstant interpretation upon CSR which might be conducted by company by elevating business ethic become legal norm; and integrate social, moral and law issue since three of them inseparable. The enactment of CSR as liability which hold sanction by Indonesia is not a form of transferring the state responsibility to corporate, however it is a manifestation of Indonesian government seriousness as the primary duty bearer, to perform its obligation concerning ESCR through effective legislation since the corporates activities are directly related to the enjoyment of the rights enshrined in the ICESCR. Allegation on the transfer of state obligation on to the company will be proved if the state is hands off and diverting its entire obligation to fulfill ESCR to company in the format of CSR program.
\end{abstract}

Keywords: social responsibility, ESCR, state responsibility

\begin{abstract}
Abstrak
Indonesia menormakan tanggung jawab social dan lingkungan (TJSL/CSR) dalam perundangundangannya sebagai suatu kewajiban yang disertai sanksi. Suatu praktek yang tidak lazim dengan praktek Negara pada umumnya yang menormakannya sebagai kesukarelaan perusahaan bukan kewajiban apalgi disertai sanksi. Hal ini menimbulkan kecurigaan bahwa Negara hendak mengalihkan tanggung jawab pemenuhan hak ekonomi, social dan budaya (ekosob)-nya kepada perusahaan yang dikemas dalam bentuk kewajiban CSR. Penormaan CSR dalam bentuk kewajiban yang disertai sanksi sesungguhnya merupakan bukti keseriusan Indonesia melaksanakan tanggung jawab hak ekosobnya melalui penglegislasian yang mengikat karena budaya hukum di Indonesia belum memungkinkan untuk membuat aturan yang sifatnya sukarela. Penormaan CSR sebagai suatu kewjaiban disertai sanksi tidak akan menghilangkan karakteristiknya sebagai social responsibility karena hukum tidak bisa dipisahkan dari social dan
\end{abstract}


moral. Masalah kerusakan alam dan masalah social yang ditimbulkan perusahaan sudah sangat besar di Indonesia, dan pengalaman menunjukkan perusahaan mampu melakukan pelanggaran HAM yang jauh lebih hebat dari yang dilakukan subyek hukum lain menjadi justifikasi bahwa penormaan yang sifatnya mengikat sangatlah diperlukan. Kecurigaan adanya modus pengalihkan tanggung jawab ekosob pada perusahaan akan terbukti bila Negara kemudian lepas tangan dan membebankan sepenuhnya tanggung jawab pemenuhan hak ekosob pada perusahaan melalui program CSR. Apabila itu terjadi maka Negara telah melakukan pelanggaran terhadap kewajiban hak ekosobnya mengingat Indonesia telah meratifikasi International Covenant on Economic Social Culture Right sejak tahun 2005 melalui UU No.11 Tahun 2005.

Kata kunci : tanggung jawab sosial, hak Ekonomi-sosial-budaya, tanggung jawab negara

\section{A. Pendahuluan}

Tanggung jawab sosial perusahaan (corporate social responsibility, CSR) telah dikenal kalangan bisnis Sejak tahun 1970'an di level internasional dan di Indonesia sejak tahun 1990'an (AB Susanto, 2007:35).Beberapa istilah yang sering digunakan Antara lain adalah tanggungjawab sosial dan lingkungan; corporate social responsibility, business social responsibility; atau corporate citizenshipAdapun Indonesia menggunakan istilah Tanggung Jawab Sosial dan Lingkungan (TJSL). Namun demikian Sampai saat ini belum didapatkan definisi CSR yang bisa diterima secara universal.

The World Business Council for Sustainable Development (WBCSD) menyebutkan CSR sebagai "continuing commitment by business to behave ethically and contribute to economic development while improving the quality of life of the workforce and their families; the local community and society at large”. Adapun John Elkingston's menegaskan “Corporate Social Responsibility is a concept that organisation especially (but not only) corporations, have an obligation to consider the interestts of costomers, employees, shareholders, communities, and ecological considerations in all aspectr of theiroperations. This obligation is been to extend beyond their statutory obligation to comply with legislation" (Sukarmi, 2014). M. Friedman menyatakan tanggung jawab perusahaan adalah tanggung jawab moral perusahaan terhadap masyarakat. Tanggung jawab ini misalnya ditujukan kepada dirinya sendiri, para karyawan, perusahaan lain, dan seterusnya. Sedangkan tanggung jawab sosial perusahaan, adalah tanggung jawab moral perusahaan terhadap masyarakat dimana perusahaan menjalankan kegiatannya, baik masyarakat dalam arti sempit seperti lingkungan disekitar sebuah pabrik atau masyarakat luas (Bertens K, 2000:292). 
Meskipun belum ada definisi yang diterima secara universal, namun secara umum CSR dapat diartikan sebagai kumpulan kebijakan dan praktik perusahaan yang berhubungan dengan stakeholder, nilai-nilai, pemenuhan ketentuan hukum, penghargaan masyarakat, lingkungan, serta komitmen dunia usaha untuk berkontribusi dalam pembangunan secara berkelanjutan (Hasan Asy’ari, 2009:viii-ix).

CSR tumbuh dan berkembang sebagai reaksi dan suara keprihatinan dari organisasiorganisasi masyarakat sipil dan jaringan tingkat global atas perilaku perusahaan yang melanggar HAM seperti perusakan lingkungan, eksploitasi sumber daya alam, ngemplang pajak, penindasan buruh, perampasan tanah rakyat, bahkan melakukan tindakan kekerasan terhadap masyarakat sekitar yang mengkritisi aktifitas komersialnya (T. Gayus Lumbuun:2014). Pelanggaran-pelanggaran yang lain adalah kondisi kerja yang tidak memenuhi standar, praktek diskriminasi berdasarkan perbedaan ras, gender, kelas, asal negara serta praktek-praktek yang dapat merusak biodiversity dan keberlangsungan lingkungan hidup (Brent McClintock, 1999:510). Kiener menyebutkan bahwa 75\% masalah sosial dan lingkungan disebabkan oleh perusahaan (Wiwik Pratiwi, 2012 : 463464).

Meskipun banyak pelanggaran yang dilakukan sebagaimana disebutkan di atas, Namun demikian ternyata cukup sulit untuk mengadili perusahaan khususnya perusahaan transnasional yang melakukan pelanggaran HAM tersebut di atas. Di tingkat internasional, perusahaan transnasional belum sepenuhnya diakui sebagai subyek hukum sehingga meskipun yang dilakukan perusahaan bisadikategorikan sebagai suatu international crime, namun pengadilan internasional seperti International Criminal Court tidak memiliki yurisdiksi terhadapnya.Ada kevakuman hukum bagi pelanggaran HAM yang dilakukan TNC ( Sefriani, 2007:65).

Di tingkat nasionalpun juga tidak mudah untuk mengadili perusahaan transnasional yang melakukan pelanggaran HAM. Hambatan-hambatan yang ditemukan di lapangan Antara lain:

1. forum non convenience

2. interfere dengan hukum nasional host state

3. Bilateral investment treaty (BIT) Antara host state dengan home state banyak yang tidak mengatur tentang pelanggaran HAM 
4. hukum nasional host state kurang perduli terhadap pelanggaran HAM yang dilakukan perusahaan transnasional karena ada ketergantungan ekonomi pada investor asing (Ilias Bantekas, 2004:310-311).

Berbagai upaya telah dilakukan untuk mengatasinya baik berupa tindakan preventif maupun represif. Salah satu upaya preventif adalah mengenalkan konsep CSR kepada pelaku usaha termasuk di dalamnya perusahaan transnasional. Konsep CSR mengakui bahwa perusahaan tidak hanya bertanggungjawab kepada shareholders-nya tetapi juga kepada orang-orang atau masyarakat yang secara langsung atau tidak langsung HAM-nya terdampak oleh aktifitas komersialnya. (OECD:2000) CSR dimaksudkan untuk meningkatkan perilaku etis, fairness dan responsibilitas korporasi yang tidak hanya terbatas pada korporasi, tetapi juga pada para stakeholder dan komunitas atau masyarakat sekitar wilayah kerja dan operasinya,(Hasan Asy’ari:2009:viii-ix) bahkan competitor dalam segala aspek operasional perusahaan (T. Gayus Lumbuun:2014).

CSR sangat erat kaitannya dengan hak ekosob. Sebagaimana diketahui Indonesia telah meratifikasi International Covenant on the Economic, Social and Cultural Rights (ICSCR) melalui UU nomor 11 tahun 2005. Konsekwensi dari peratifikasian ini adalah bahwa Pemerintah Indonesia wajib merumuskan langkah-langkah kongkrit perbaikan kondisi pemenuhan dan perlindungan hak-hak ekonomi, social dan budaya (ekosob) kepada rakyatnya. (General Comment No. 3/1990: 10)Langkah-langkah tersebut antara lain adalah :

1. Melakukan review terhadap semua peraturan perundangan, regulasi dan kebijakan yang menghambat pelaksanaan Kovenan.

2. Melakukan harmonisasi dan sinkronisasi antara hukum nasional dengan standar internasional yang berlaku

3. Melakukan relokasi sumber daya yang dimiliki negara, dalam kondisi tingkat ekonomi negara seperti apa pun untuk memprioritaskan kebijakan penghapusan kemiskinan dan pemenuhan kebutuhan minimum kepada kelompok rakyat miskin, kelompok masyarakat adat serta kelompok minoritas sebagai wujud kesungguhan Pemerintah memenuhi hak ekosob warganya (Rahayu: 2010:8-9).

Negara adalah aktor utama (the real actors) yang bertanggung jawab pada pemenuhan, perlindungan, penghormatan dan pemajuan hak ekosob. The UN Framework and the Guiding Principles 2011 (UN Guiding principle 2011) secara jelas menegaskan perbedaan Antara the duty of the state dengan the responsibility of business. Negara tidak 
diijinkan menghindari kewajibannya dengan mentransfer tanggungjawabnya kepada pemangku hak (rights-holders) (ITUC CSI IGB, 2012:5).

Di sisi lain ada kecurigaan bahwa Indonesia berupaya mentransfer tanggung jawab ekosobnya kepada perusahaan melalui CSR. Beberapa peraturan perundang-undangan Indonesia khususnya Undang-Undang Nomor 40 Tahun 2007 tentang Perseroan Terbatas, Undang-Undang Nomor 25 tahun 2007 tentang Penanaman Modal, juga Peraturan Pemerintah Nomor 47 Tahun 2012 tentang Tanggung Jawab Sosial dan Lingkungan mewajibkan perusahaan untuk menganggarkan dana yang dihitung sebagai dana operasional perusahaan untuk tujuan tanggung jawab social dan lingkungan (TJSL/CSR). Kewajiban ini disertai sanksi bagi pelanggarnya (Pasal 74 UU 40 Tahun 2007 dan Pasal 15 UU nomor 25 Tahun 2007). Sanksi dalam UU penanaman modal misalnya mulai dari peringatan tertulis, pembatasan kegiatan usaha, pembekuan kegiatan usaha dan/atau fasilitas penanaman modal, atau pencabutan kegiatan usaha dan /atau fasilitas penanaman modal. Baik UU Penanaman modal atau UU tentang PT tidak menyebutkan ruang lingkup TJSL/CSR, namun dalam praktek program yang dilakukan perusahaan di Indonesia masih focus hanya pada community development, yaitu pada pemenuhan kebutuhan dasar hak ekosob seperti makanan, tempat tinggal, pendidikan, infrastruktur dan kesehatan, Satu bidang saja dari tiga bidang yang seharusnya diintegrasikan dalam CSR (Noke Kiroyan:2007:2).

Penormaan TJSL/CSR sebagai kewajiban yang disertai sanksi dirasa memberatkan oleh kalangan bisnis di Indonesia (http://www.hukumonline.com/berita/baca/lt4cbf5a4325dfd/mempermasalahkan-lagitanggung-jawab-sosial-perusahaan) Keberatan ini diwujudkan dengan mengajukan judicial review UU PT ke MK khususnya menyangkut Pasal 74 beserta penjelasannya yang mewajibkan perusahaan yang menjalankan kegiatan usahanya di bidang dan/atau berkaitan dengan sumber daya alam menganggarkan dana untuk dan bagi perusahan yang tidak melaksanakan akan dikenai sanksi.. Para pemohon yang antara lain diwakili oleh Ketua Umum Pengurus Kamar Dagang dan Industri (KADIN); Ketua Umum Badan Pengurus Pusat Himpunan Pengusaha Muda Indonesia (BPP HIPMI); Ketua Umum Ikatan Wanita Pengusaha Indonesia (IWAPI), PT Lili Panma; PT. APAC CENTRA CENTERTEX, Tbk; serta PT. Kreasi tiga pilar menganggap kewajiban TJSL 
memberatkan keuangan perusahaan yang akan mengurangi daya saing mereka di pasar global (Putusan MK Nomor 53/PUU-VI/2008:11).

Para pemohon juga menyatakan bahwa Penormaan sebagaimana dicantumkan dalam UU PT menyebabkan terjadinya ketidakjelasan antara tanggung jawab yang didasarkan atas karakter sosial (socialresponsibility) yang bersifat voluntary dengan kewajiban yang bersifat hukum (legal obligation) yang mempunyai daya memaksa (Putusan MK Nomor 53/PUU-VI/2008:13; 37). Menurut para pemohon, Indonesia adalah satu-satunya Negara di dunia yang mewajibkan TJSl/CSR disertai sanksi. TJSL/CSR di Indonesia juga dianggap diskriminatif karena hanya diterapkan untuk perusahaan yang bergerak di bidang sumber daya alam dan duplikasi atau tumpang tindih dengan undang-undang sektoral yang sesungguhnya sudah mengatur hal tersebut.

Lebih lanjut, para pemohon menyatakan bahwa kewajiban TJSL/CSR yang disertai sanksi merupakan privatisasi fungsi negara pada dunia usaha. Hal ini dikarenakan Negara telah mengalihkan kewajiban dan tanggung jawabnya untukmengembangkan sistem jaminan sosial bagi seluruh rakyat dan memberdayakan masyarakat yang lemah dan tidak mampu sesuai dengan martabat kemanusiaan serta juga bertanggung jawab atas penyediaan fasilitas pelayanan kesehatan dan fasilitas pelayanan umum yang layak (Putusan MK Nomor 53/PUU-VI/2008:15).

Banyak tuduhan skeptis bahwa penormaan CSR sebagai suatu kewajiban yang disertai sanksi menunjukkan bahwa pemerintah memaknai CSR hanya dari sisi peluang sumber daya finansial perusahaan yang dapat dimanfaatkan untuk mengalihkan beban pembangunan kepada perusahaan. Konsekwensi regulasi semacam ini akan mengarahkan Aktivitas CSR sebagai tanggung jawab legal formal yang terkesan basa basi dan mengabaikan sejumlah prasyarat yang memungkinkan terwujudnya makna dasar CSR itu sendiri (Hasan Asy’ari:2009:viii-ix).

Berdasarkan paparan di atas maka tulisan ini menganalisis secara mendalam Bagaimana legitimasi penormaan TJSL/CSR sebagai suatu kewajiban yang disertai sanksi dalam perundang-undangan Indonesia? Apakah penormaan TJSL/CSR yang bersifat wajib disertai sanksi dalam peraturan perundang-undangan Indonesia merupakan bentuk pengalihan tanggung jawab Negara kepada perusahaan? 


\section{B. Metode Penelitian}

Penelitian ini merupakan penelitian hukum normatif yang menggunakan data sekunder yang terdiri dari bahan hukum primer, sekunder dan tersier. Semua bahan hukum yang diperoleh dalam penelitian akan dikumpulkan, dikelompokkan sesuai variabel masingmasing, untuk selanjutnya dianalisis secara kualitatif. dengan menggunakan beberapa pendekatan. Beberapa pendekatan yang digunakan dalam penelitian ini adalah pendekatan perundang-undangan (statute approach), pendekatan histories, pendekatan konsep (conceptual approach), serta pendekatan perbandingan (comparative approach). (Peter Mahmud Marzuki:2005:93-95). Hasil dari penelitian ini akan disajikan dalam bentuk deskriptif analitis.

\section{Hasil Penelitian dan Pembahasan}

\section{Legitimasi Penormaan TJSI/CSR Sebagai suatu kewajiban yang disertai sanksi di} Indonesia

Dalam praktek global,CSR merupakan program bersifat sukarela yang memiliki variasi beragam yang diharapkan dapat menguntungkan perusahaan dan masyarakat. (http://www.hukumonline.com/berita/baca/lt4d000f3828437/pemenuhan-hak-ekosobbukan-semata-tanggung-jawab-negara) Mengapa Indonesia menormakan CSR sebagai suatu kewajiban disertai sanksi, bukan sebagai sesuatu yang sifatnya sukarela (voluntary) akan dilihat dari argument hukum para pakar maupun putusan pengadilan Indonesia di bawah ini.

Menurut Gayus Lumbuun, penormaan TJSL/CSR di Indonesia sebagai kewajiban yang disertai sanksi bagi pelanggarnya dimaksudkan untuk lebih memberi daya atur, daya ikat, dan daya paksa tanggung jawab perusahaan dari semula responsibility (tanggung jawab non hukum) menjadi liability (tanggung jawab hukum) (T. Gayus Lumbuun, 2014)

Penormaan CSR sebagai suatu kewajiban yang disertai sanksi telah dikuatkan Mahkamah Konstitusi dalam putusannnya Nomor 53/PUU-VI/2008. Nomor 53/PUUVI/2008 Penormaan TJSL sebagai kewajiban diserta sanksi sudah tepat menurut MK mengingat (T. Gayus Lumbuun, 2014). 
1. Secara faktual, kondisi sosial dan lingkungan telah rusak di masa lalu ketika perusahaan mengabaikan aspek sosial dan lingkungan sehingga merugikan masyarakat sekitar dan lingkungan pada umumnya.

2. Budaya hukum di Indonesia tidak sama dengan budaya hukum negara lain, utamanya negara industri maju tempat konsep CSR pertama kali diperkenalkan di mana CSR bukan hanya merupakan tuntutan bagi perusahaan kepada masyarakat dan lingkungannya tetapi juga telah dijadikan sebagai salah satu indikator kinerja perusahaan dan syarat bagi perusahaan yang akan go public. Dengan kata lain, MK berpendapat bahwa sesuai kultur hukum Indonesia, penormaan TJSL sebagai norma hukum yang diancam dengan sanksi hukum merupakan suatu keharusan demi tegaknya TJSL atau CSR.

3. untuk memberikan kepastian hukum sebab dapat menghindari terjadinya penafsiran yang berbeda-beda tentang TJSL oleh perseroan sebagaimana dapat terjadi bila TJSL dibiarkan bersifat sukarela. Hanya dengan cara memaksa tersebut akan dapat diharapkan adanya kontribusi perusahaan untuk ikut meningkatkan kesejahteraan masyarakat

4. hubungan antara moral dan etik dengan hukum adalah bersifat gradual, dimana hukum merupakan formalisasi atau legalisasi dari nilai-nilai moral. Dalam hubungan ini, nilainilai moral dan etik yang diterima secara sukarela (voluntary) dan dianggap penting dapat saja diubah secara gradual menjadi hukum atau Undang-Undang agar lebih mengikat. Dengan demikian menurut MK tidak ada halangan apapun terhadap nilai-nilai CSR yang semula bersifat ketentuan moral, etik, dan sukarela (voluntary), kemudian dijadikan suatu kewajiban dalam Undang-Undang(Putusan MK Nomor 53/PUU-VI/2008:91-92)

Disamping argument yang diberikan MK, tiga argumen lain yang mendukung Penormaan TJSL/CSR sebagai suatu kewajiban yang disertai sanksi adalah sebagai berikut pertama adalah untuk mengintegrasikan ekonomi dengan HAM. Masyarakat Eropa sudah belajar dari sejarah bahwa ekonomi, politik, dan kebebasan hukum tidak bisa dipisahkan sama sekali. Kolaborasi industry dengan NAZI di Jerman pada Perang Dunia ke II memberikan fakta bahwa private economic power tidak kurang bahayanya bagi human dignity dibandingkan militer. (Pall A. Davidsson:2002:547). Oleh karenanya sangat penting mengintegrasikan ekonomi dengan perlindungan HAM, memajukan human welfare melalui integrasi ekonomi dengan factor social.dalam bentuk ketentuan hukum yang mengikat. Kedua, Penormaan sukarela yang menyerahkan perencanaan program CSR pada persahaan terbukti tidak efektif, hanya menjadi sarana untuk promosi, iklan dan public relation. Masyarakat miskin di Negara berkembang dan terbelakang yang menduga akan diuntungkan dari program CSR yang dirancang perusahaan kenyatannya hanya mendapat efek buruk dari rusaknya lingkungan akibat aktifitas perusahaan. CSR sukarela tidak berhasil mengubah perilaku perusahaan terhadap 
HAM, justru semakin menggerogoti kedaulatan negara (Kunnawee Thirarungrueang, 2013:175-176). Ketiga, sulit menerima argument bahwa CSR akan kehilangan karakteristiknya sebagai social responsibility jika diatur dalam norma hukum yang bersifat wajib, mengikat dan disertai sanksi karena seolah-olah hukum tidak memiliki nilai-nilai social dan moral. Hal ini tidak bisa diterima karena social dan moral adalah inti dari banyak aturan hukum. Keduanya bagaikan dua sisi dari mata uang yang sama yang tidak dapat terpisahkan. Sebagai contoh kewajiban hukum yang diberikan pada orang tua terhadap anaknya tidak menghapuskan kewajiban sosial dan moralnya. Masyarakat Eropa sudah memiliki tradisi mengintegrasikan masalah sosial ke dalam hukum bisnis mereka. Pengaturan perlindungan lingkungan, upah minimum dan keselamatan kerja adalah contoh-contoh dari penglegislasiannya (Pall A. Davidsson:2002:545).

Penormaan CSR sebagai suatu kewajiban disertai sanksi justru menunjukkan keseriusan pemerintah Indonesia dalam mengimplementasikan instrument HAM internasional yang menetapkan Negara sebagai the primary duty bearer. Negara harus bisa melindungi, memenuhi, menghormati, juga memajukan hak ekosob warganya melalui peraturan perundang-undangan yang dibuatnya, jangan sampai penikmatan hak ekosob masyarakat Indonesia terhalang akibat aktifitas perusahaan.(Pall A. Davidsson:2002:547).The Maastricht Guidelines on Violations of Economic, Social and Cultural Rightsmenuntut Negara untuk menjamin bahwa TNC tidak mencabut HAM individu atau masyarakat. (Daniel Aguirre:2011:125) Pasal 2 ICESCR menegaskan bahwa:

Each State Party to the present Covenant undertakes to take steps, individually and through international assistance and co-operation, especially economic and technical, to the maximum of its available resources, with a view to achieving progressively the full realisation of the rights recognized in the present Covenant by all appropriate means, including particularly the adoption of legislative measures

Selanjutnya UN Guiding Principle 2011 juga mewajibkan Negara untuk : melindungi dari pelanggaran HAM pihak ketiga termasuk perusahaan bisnis, di dalam wilayah dan atau yurisdiksinya. Negara wajib melakukan langkah-langkah yang pantas untuk mencegah, menyelidiki, menghkum, dan memulihkan pelanggaran tersebut melalui legislasi, peraturan, dan system peradilan yang efektif.(ELSAM: 2012:14-15) 
Penormaan TJSL/CSR sebagai suatu kewajiban yang disertai sanksi sah-sah saja dilakukan oleh Pemerintah Indonesia sebagai Negara yang berdaulat,untuk menunjukkan keseriusannya mengimplementasikan kewajiban HAM bagi Negara sekalipun tidak sesuai dengan apa yang dipraktekkan Negara lain yang hanya mengaturnya sebagai sesuatu yang sifatnya sukarela dan pelaksanaannya diserahkan kepada perusahaan.Sesuatu yang berbeda dengan praktek di tingkat internasional, belum tentu merupakan hal yang buruk. Apa yang dilakukan Indonesia menjadikan CSR sebagai suatu kewajiban disertai sanksi bisa jadi merupakan refleksi dari kebutuhan hukum yang baru karena prektek hukum yang lama tidak mencukupi kebutuhan lagi. Sepak terjang perusahaan transnasional yang semakin mengkhawatirkan pemenuhan dan perlindungan HAM masyarakat sekelilingnya tidak bisa lagi hanya diatasi dengan aturan yang sifatnya voluntary. Apabila yang dilakukan Indonesia membawa dampak positif dan diikuti oleh Negara-negara lain tidak mustahil bahwa yang semula dianggap sebagai suatu anomaly atau pelanggaran justru diakui dan diikuti menjadi kaedah hukum yang baru. Sebagai Negara berdaulat, Indonesia berhak untuk mengatur hukumnya sendiri yang tidak tergantung pada hukum dan budaya yang berlaku di negara lain. Indonesia memiliki alasan tersendiri mengapa CSR yang berlaku di Indonesia tidak disamakan dengan CSR yang berlaku di negara-negara lain, misalnya di Inggris, Belanda, Kanada, Perancis, Jerman, dan Amerika Serikat, dimana CSR sifatnya voluntary. Di negara-negara tersebut CSR sudah sedemikian popular. perusahaan telah menyadari begitu pentingnya CSR untuk mendukung kelangsungan hidup perusahaan

Fakta menunjukkan begitu banyak perusahaan transnasional yang menguras habis sumber kekayaan alam di Indonesia, hanya menyisakan kerusakan lingkungan yang parah, merampas hak masyarakat local atas lingkungan yang sehat,merampas hak atas air masyarakat localdan semakin memarginalkan masyarakat local yang tergusur karena keberadaan para pemilik modal tersebut. Belum lagi lingkungan kerja yang tidak memenuhi standar keselamatan pekerja, diskriminasi upah berdasarkan etnis, nasionalitas, sex, bahkan kekerasan yang dilakukan perusahaan yang berkolaborasi dengan aparat keamanan terhadap masyarakat lokal, aktifis HAM atau serikat buruh yang mengkritisi kebijakan perusahaan yang tidak adil. 
Di masa lalu, perusahaan khususnya TNC sering dipuja sebagai agen pembangunan (Sumantoro, 1984:151), memberikan harapan-harapan untuk meningkatkan perekonomian Indonesia mengingat TNC tersebut bisa memberikan lapangan pekerjaan, membawa modal dan teknologi yang tidak dimiliki oleh Indonesia, memberi pelatihan kepada tenaga kerja-tenaga kerja Indonesia. Namun demikian sebagaimana telah disebutkan sebelumnya di sisi lain TNC-TNC itu juga memberikan dampak buruk kepada HAM masyarakat Indonesia.

Fakta menunjukkan pula bahwa banyak Negara berkembang dan terbelakang tidak memiliki keberanian untuk mengatur aktifitas TNC karena dengan modal dan teknologi yang mereka miliki, TNC bisa memaksakan kehendak pada Negara untuk menbuat aturan-aturan yang longgar terkait lingkungan, perpajakan, buruh, dengan ancaman akan memindahkan operasional mereka ke Negara lain bila host state tidak mau memenuhi keinginan mereka. Atas nama kompetisi untuk menarik investasi asing banyak Negara berkembang dan terbelakang rela kedaulatannya tereduksi(Daniel Aguirre:2011:57-58), mengikuti kemauan TNC dan mengabaikan pemenuhan HAM khususnya hak eksosob warganya. Dengan demikian penormaan CSR sebagai suatu kewajiban yang disertai sanksi merupakan kemajuan dan tindakan berani Pemerintah Indonesia. Tindakan ini dilakukan untuk mewujudkan tanggung jawab Negara Indonesia sebagai the primary duty bearer terhadap pemenuhan, perlindungan, penghornatan dan pemajuan HAM, khususnya hak ekososb masyarakat Indonesia, sekalipun mungkin penormaan seperti ini dianggap tidak populis bagi perusahaan dan beresiko mengancam competitiveness Indonesia untuk menarik masuknya modal asing. Perusahaan termasuk di dalamnya TNC yang kegiatannya berpotensi atau nyata-nyata telah melanggar hak eksosob harus bisa dimintai pertanggungjawaban, sehingga Negara harus memiliki kemauan politik melegislasikan pencegahan dampak buruk pelanggaran HAM akibat aktifitas perusahaan dan mengembangkan judicial system yang mampu mengadili kasus-kasus pelanggaran hak ekosob (Daniel Aguirre, 2011:130). Indonesia sebagai pihak yang paing terdampak akibat aktifitas komersial perusahaan termasuk TNC tidak bisa menyerahkan mekanisme pertanggungjawaban kepada pengadilan home state ataupun pengadilan internasional karena sampai saat ini tidak ada good political will yang mengakibatkan sulitnya menuntut perusahaan baik di depan pengadilan internasional maupun nasional. 
Untuk mengatasinya Indonesia harus memiliki metode dan strategi tersendiri bagaimana merumuskan CSR yang mengatur keberadaan perusahaan agar memberikan manfaat sebesar-besarnya pada masyarakat local, mempunyai daya paksa, tetapi tidak mengurangi competitiveness Indonesia dalam memperebutkan modal asing yang memang sangat dibutuhkan oleh negara untuk melakukan pembangunan.

\section{Penormaan TJSL/CSR di Indonesia berpotensi Menjadi Upaya Pengalihan Tanggung Jawab Ekosob Negara kepada perusahaan}

Hukum HAM internasional menegaskan bahwa ada dua kewajiban hukum utama negara, yang terdiri dari primary Rules dan secondary rules. Primary Rules, yaitu the duty to abstain from infringing upon human rights. Kewajiban ini berkenaan dengan kewajiban negara untuk tidak melakukan pelanggaran HAM baik melalui tindakan maupun pendiaman, termasuk menjamin pemenuhan secara aktif hak-hak tersebut. Kewajiban dalam primary rules masih diklasifikasikan lagi menjadi tiga bentuk kewajiban. Pertama, Kewajiban menghormati (to respect). Kewajiban ini menuntut negara, dan semua organ dan aparatnya, untuk tidak bertindak apapun yang justru membatasi sebagian atau seluruhnya hak-hak ekosob masyarakat. Pembatasan hanya dapat dilakukan dengan maksud agar terpenuhinya hak-hak itu sendiri. Contoh yang dapat diberikan misalnya negara tidak diperkenankan untuk melakukan intervensi baik melalui peraturan perundangan atau kebijakan, maupun campur tangan langsung hak seseorang atau kelompok untuk membentuk serikat buruh/pekerja atas pilihannya sendiri atau melakukan pemogokan (Pasal 8 Kovenan) (Yosep Adi Prasetyo:2012:10-11). Kedua, Kewajiban melindungi (to protect). Kewajiban ini menuntut negara dan aparatnya melakukan tindakan yang memadai guna mencegah dan melindungi warga individu dari pelanggaran hak-hak individu atau kelompok oleh pihak ketiga. Contoh dari pelanggaran kewajiban ini adalah Kegagalan untuk bertindak, ketika satu kelompok preman atas perintah investor besar melakukan intimidasi untuk mengusir warga dari rumahnya yang diklaim sebagai milik si investor, juga kegagalan untuk memaksa perusahaan untuk membayar upah sebesar upah minimum yang telah ditetapkan, membayar tunjangan hari raya, dan lain-lain.Ketiga, Kewajiban memenuhi (to fulfil). Kewajiban ini menuntut negara mengambil tindakan-tindakan legislatif, administratif, finansial, hukum, dan tindakan-tindakan lain yang memadai untuk menjamin setiap orang di dalam 
yurisdiksinya dapat menikmati Hak ekosob yang tidak dapat dipenuhi oleh upaya pribadi. Perwujudan obligasi Negara untuk pemenuhan hak ekosob mencakup sebagai berikut (Yosep Adi Prasetyo:2012:11).

1. Menyediakan lapangan kerja dan memfasilitasi bimbingan teknis, programprogram pelatihan, dan kegiatan ekonomi produktif (Pasal 6 ICESR)

2. Menyediakan dan memfasilitasi jaminan sosial termasuk asuransi sosial bagi setiap warga negara (Pasal 9 ICESR);

3. Menyediakan bantuan kepada keluarga untuk merawat dan mendidik anak-anak yang masih dalam tanggungannya (Pasal 10 ICESR)

4. Dengan kerjasama internasional, Negara menyediakan dan memfasilitasi (akses) atas pangan, sandang dan perumahan, dan perbaikan kondisi hidup semua orang secara terus menerus (Pasal 11 ICESR);

5. Menyediakan dan memfasilitasi (akses) atas standar kesehatan fisik dan mental setinggi-tingginya yang dapat dicapai (Pasal 12 ICESR);

6. Menyediakan dan memfasilitasi (akses) atas pendidikan, termasuk memenuhi hak setiaporang menikmati pendidikan dasar yang wajib dan cuma-cuma (compulsory and free of charge) (Pasal13 dan 14 ICESR)

7. Menyediakan dan memfasilitasi (akses) semua orang untuk menikmati manfaat darikemajuan ilmu pengetahuan dan penerapannya (Pasal 15 ayat (1) ICESR);

Adapun pelanggaran terhadap kewajiban ekosob ini misalnya adalah kegagalan negara untuk memenuhi sistem perawatan kesehatan dasar serta Kegagalan untuk mengimplementasikan satu sistem pendidikan gratis pada tingkat primer.

Adapun Secondary Rules, yaitu the duty to guarantee respect of human rights. Kewajiban ini berkenaan dengan kewajiban negara untuk mencegah pelanggaran, meyelidikinya ketika terjadi, melakukan proses hukum kepada pelaku, serta melakukan reparasi atas kerugian yang timbul. Kewajiban dalam secondary rules masih diklasifikasikan lagi menjadi dua bentuk kewajiban di dalamnya, pertama, Kewajiban mengenai tindakan (oligation of conduct) yaitu kewajiban mengenai tindakan untuk melaksanakan dipenuhinya suatu hak. Kedua, Kewajiban mengenai hasil (obligation of result) yaitu kewajiban berkenaan dengan keharusan negara mencapai target-target tertentu. 
Dari paparan di atas nampak bahwa negara adalah pengemban utama tanggung jawab untuk memenuhi, melindungi, menghormati dan memajukan hak ekosob. Pemenuhan hak ekosob memang menuntut biaya tinggi yang terkadang dirasa berat oleh negara untuk melaksanakannya. Namun demikian Negara tidak bisa tidak memang harus memenuhi hak-hak warganegara, termasuk hakatas perumahan, hak atas pangan, hak ataspendidikan, hak atas pekerjaan, dan berbagai hak ekosob yang lain.Sesulit apapun tantangan yang dihadapi oleh pemerintah dalam memenuhi hak ekosob tetap itu adalah bagian dari tanggung jawab negara. Negara tidak bisa menunda, mentransfer, atau bahkan menghilangkan hak-hak tersebut dengan dalih keterbatasan sumberdaya yang dimiliki, atau karena faktor-faktor eksternal lainnya.(R. Herlambang Perdana:2014).Lebih lanjut, ICESCR memberi kewajiban pada Negara untuk merealisasikan hak eksosob secara progresif, dan mencegah tidak terjadi perkembangan regresif atau kemunduran. Jika hal itu terpaksa dilakukan atau terjadi, maka harus dijalankan dengan pertimbangan yang sangat hati-hati disertai suatu justifikasi penuh dengan mengacu pada inti hakyang ditentukan dalam Kovenan dan dalam konteks pemanfaatan sejauh mungkin atas sumberdaya yang ada. Kemunduran semisal rakyat hidup dalam kemiskinan dan kelaparan dapat dijustifikasi hanya apabila negara bisa membuktikan bahwa kegagalannya memenuhi hak-hak orang-orang ini memang diluar kendali.

Fakta menunjukkan bahwa negara memiliki keterbatasan untuk memenuhi hak-hak ekosob terutama disebabkan keterbatasan biaya. Hal ini disadari betul oleh negara-negara yang turut merumuskan pembahasan konvensi Ekosob, sehingga dalam kovenan mengenai hak-hak ekonomi, sosial dan budaya memperbolehkan negara mencapai pemenuhan hak-hak tersebut secara bertahap.Selain itu, negara dalam perannya sebagai penanggung jawab tidak bertindak secara langsung sebagai penyedia bagi apa yang dibutuhkan bagi pemenuhan hak asasi tertentu. Namun juga dapat dibantu oleh pihakpihak lain yang memiliki kepedulian dalam memajukan hak-hak ekosob. Pada wilayah inilah perusahaan dengan tanggung jawab sosialnya berperan membantu negara memenuhi hak-hak tersebut (Giri Ahmad Taufik, 2014). Untuk menunjukkan bahwa partisipasi actor non Negara diharapkan dalam pelaksanaan hak eksosob dapat dirujuk Antara lain General Comments No. 12 and 14 on the right to adequatefood (para. 20) 
juga hak untuk mendapatkan standar tertinggibidang kesehatan (para. 42) menegaskan

.....that while states are parties to the Covenant on Economic, Social and Cultural Rights and therefore ultimately accountable for complying with it, all members of society, including individuals and the private business sector, have responsibilities for the realization of the right to adequate food respectively the right to the highest attainable standard of health

Dari General Comment di atas nampak bahwa non state actor pun memiliki tanggung jawab terhadap realisasi hak atas makanan dan hak atas kesehatan (Karin Buhman, 2012:337). Hal ini mengubah pandangan klasik bahwa hanya Negara satu-satunya yang memiliki kewajiban HAM.

Perkembangan terbaru relasi bisnis dengan HAM dapat dilihat di UN Guiding principle tentang hubungan bisnis dengan HAM. Guiding principle ini memuat 3 pilar sebagai berikut:

1. Kewajiban Negara untuk melindungi HAM, dimana pemerintah harus melindungi individu dari pelanggaran HAM oleh pihak ketiga termasuk bisnis

2. Tanggung jawab perusahaan untuk menghormati HAM, yang berarti tidak melanggar HAM yang diakui internasional dengan menghindari, mengurangi, atau mencegah dampak negatif dari operasional korporasi dan

3. Kebutuhan untuk memperluas akses bagi korban mendapatkan pemulihan yang efektif baik melalui mekanisme yudisial maupun non yudisial (Christian Dony Putranto (penterjemah), 2012:vii)

Pilar pertama guiding principle mengatur tentang peran negara. Negara harus melindungi masyarakatnya dari tindakan pelanggaran (abusing) HAM di wilayahnya atau yurisdiksinya termasuk pelanggaran yang dilakukan oleh kalangan bisnis. Fungsi Negara yang dihubungkan dengan TJSL/CSR antara lain adalah fungsi regulator. Melalui kewenangan yang dimilikinya negara harus bisa menyusun instrumen yuridis pengaturan TJSL/CSR yang bisa memberikanm kesejahteraan bagi warga masyarakat (Arifin Imamul, 2011). Pelaksanaan TJSL/CSR harus memberi manfaat kepada masyarakat sekitar melalui peran perusahaan dan pemerintah. Koordinasi dan sinergitas para stakeholder dalam pelaksanaan TJSL/CSR dalam meningkatkan kualitas masyarakat sebagai perwujudan fungsi Negara mensejahterakan warganya (Moh Rivai Anwar\&M. Yunus Wahid, Abrar Saleng, 2014). 
Hal yang harus digarisbawahi adalah The UN Framework and the Guiding Principles 2011 secara jelas menegaskan perbedaan antara the duty of the state dengan the responsibility of business. Hal ini yang membuat guiding principle lebih realistis dibanding instrument hukum internasional yang lain. Menurut Guiding principle Negara tetap sebagai aktor utama, the real actors yang bertanggung jawab pada pemenuhan, perlindungan, penghormatan dan pemajuan HAM. Hal ini tidak boleh dicampur adukkan dengan pernyataan-pernyataan seperti saling melengkapi (complementary) atau sebagai solusi mengatasi keterbatasan dana pemerintah. Negara tidak diijinkan menghindari kewajibannya dengan mentransfer tanggungjawabnya kepada pemangku hak (rightsholders) (ITUC CSI IGB:5). Adapun tanggung jawab perusahaan adalah sebatas untuk menghormati HAM, yang artinya perusahaan dituntut untuk tidak melanggar (infringe) hak pihak lain, tidak terlibat dalam pelanggaran HAM yang dilakukan perusahaan afiliasinya. (Radu Mares, 2010:5). Kewajiban Perusahaan ini merupakan kewajiban yang self standingand independent dari kegagalan Negara untuk melaksanakan kewajiban HAM-nya (Radu Mares, 2010:34).

Menurut Ruggie, kewajiban perusahaan untuk tidak melanggar HAM merupakan suatu minimum responsibility. Kewajiban ini berlaku untuk semua kategori perusahaan baik TNC ternama ataupun perusahaan kecil (Radu Mares, 2010:38). Apa yang dikemukakan Ruggie di atas bahwa kewajiban perusahaan untuk tidak melanggar HAM merupakan suatu minimal responsibility artinya perusahaan dapat diminta untuk melakukan lebih daripada itu termasuk di dalamnya melakukan tanggung jawab sosial. Perusahaan adalah juga pribadi social meskipun artifisial, sehingga ia juga memiliki tanggung jawab social. Perusahaan tidak dibenarkan mencari keuntungan dengan mengorbankan pihak-pihak lain, termasuk kepentingan masyarakat luas tapi sebaliknya punya tanggung jawab menciptakan masyarakat yang baik dan sejahtera (T. Gayus Lumbuun, 2014). Ruang lingkup tanggung jawab sosial perusahaan menurut Sony Keraf adalah pertama terlibat dalam kegiatan social yang berguna untuk kemajuan dan kesejahteraan masyarakat, kedua keuntungan ekonomi, ketiga ketaatan hukum, dan keempat adalah hormat pada hak dan kepentingan stakeholder atau pihak-pihak terkait secara langsung atau tidak langsung dengan kegiatan bisnis perusahaan (A. Sony Keraf, 1998:123-127). 
Kecurigaan bahwa konsep TJSL/CSR dalam perundang-undangan Indonesia yang bersifat wajib dengan disertai sanksi bagi pelanggarnya merupakan upaya pengalihan tanggung jawab ekosob Negara kepada perusahaan tidak terbukti apabila Negara tidak lepas tangan atau membebankan seluruh tanggung jawab memenuhi ekosob itu kepada perusahaan yang terkena kewajiban. Sebagai Negara berdaulat yang telah meratifikasi ICESCR Indonesia memang wajib mengatur segala aktifitas perusahaan yang di wilayahnya termasuk mewajibkan perusahaan melakukan CSR. Hal ini untuk melaksanakan tanggung jawab Negara Indonesia melindungi, juga memenuhi hak ekososb masyarakat Indonesia, karena sebagaimana diketahui 75 \% masalah social dan kerusakan lingkungan diakibatan oleh aktifitas komersial perusahaan terutama TNC. Sebagai negara yang berdaulat, Indonesia berhak memformulasikan sekaligus melaksanakan ancaman sanksi bagi perusahaan yang tidak melaksanakannya. Negara harus memposisikan diri sebagai regulator, pengarah dan perencana konsep besar CSR, penanggung jawab utama dan memastikan tersedia dan tersalurkannya dana CSR untuk melindungi hak ekosob melalui program CSR, tidak hanya sebagai regulator saja. Negara harus mengatur, mengkoordinasikan dan melakukan pengawasan pelaksanaan CSR, tidak bisa menyerahkan semuanya kepada perusahaan. Hal ini dikarenakan fakta menunjukkan bahwa CSR tidak efektif jika sifatnya sukarela dan pelaksanaanya diserahkan kepada perusahaan melalui self regulation perusahan. Survey pelaksanaan CSR di tahun 2005, saat CSR belum diwajibkan dan belum ada sanksi, menunjukkan bahwa dari 166 atau 44,27\% perusahaan menyatakan tidak melaksanakan CSR (Wiwik Patiwi, 2012:462).

Negara, perusahaan dan masyarakat lokal saling membutuhkan satu sama lain. Investasi korporasi adalah mesin utama penggerak pertumbuhan ekonomi. Pertumbuhan ekonomi sendiri penting untuk meningkatkan sumber-sumber yang tersedia untuk pemenuhan hak ekosob (Daniel Aguirre, 2011:132). Kemajuan perusahaan akan membuka banyak lapangan kerja, mensejahterahkan warga dan mempercepat pembangunan nasional. Di sisi lain perusahaan juga membutuhkan peran negara untuk menjaga kestabilan politik, suasana kerja yang kondusif, dan peraturan-pertauran investasi yang memberi kepastian hukum dan tidak memberatkan perusahaan. Selanjutnya perusahaan juga membutuhkan masyarakat lokal untuk memasarkan 
produknya, menyediakan tenaga kerja, menjaga keamanan dan kestabilan lingkungan perusahaan.

Agar negara tidak dituduh mengalihkan tanggung jawab ekosobnya kepada perusahaan dengan kedok CSR maka negara harus berfungsi sebagai berikut pertama Memfasilitasi penyelenggaraan program kegiatan CSR termasuk memberikan insentif bagi penyelenggaraan yang berhasil baik, kedua, Negara harus bisa Mensinergikanprogram dan kegiatan perusahaan dengan program dan kegiatan Pemerintah dalam rangka pelaksanaan pembangunan berkelanjutan yang lebih efektif dan terpadu selaras dengan prinsip 3P yaitu planet, people dan profit. Program TJSL/CSR yang baik diwujudkan dalam bentuk kemitraan antara perusahaan dengan seluruh stake holder, pemerintah, LSM, juga komunitas lokal (setempat). Kemitraan ini tidaklah bersifat pasif dan statis. Kemitraan ini merupakan tanggung jawab bersama secara sosial antara stakeholders (Hasan Asy'ari, 2009:20). Negara tetap dalam posisi sebagai penanggung jawab utama untuk melindungi, memenuhi, menghormati dan memajukan HAM. Negara tidak boleh mengalihkan tanggung jawab ini kepada perusahaan, tetapi Negara dapat melibatkan perusahaan melalui program CSR untuk mencapai pembangunan yang berkelanjutan. Belajar dari praktek yang dilakukan Cina ada berbagai peran yang dilakukan Negara dalam pelaksanaan CSR yaitu endorsing; Facilitating; Partnering; Mandating dan Principal-Agent Controls (Virginia Harper Ho, 2013:442). Dengan demikian, negara tidak lepas tangan terhadap tanggung jawab ekosobnya, negara tetap menjadi penanggung jawab utama.

Di sisi lain, penormaan CSR sebagai suatu kewajiban yang disertai sanksi akan menjadi bentuk pengalihan tanggung jawab Negara kepada perusahan dengan berkedok CSR bilamana Negara hanya membuat aturan, memaksa perusahaan memberikan berbagai sumbangan untuk masyarakat sekitar, dan menjatuhkan sanksi bagi yang tidak mau memberikan sanksi. Negara mengurangi atau bahkan sama sekali tidak menganggarkan dalam APBN atau APBD-nya dana untuk pemenuhan ekosob karena sudah digantikan oleh perusahaan. Negara juga bersikap masa bodoh terhadap program yang dilakukan perusahaan mendukung pembangunan berkelanjutan ataukah hanya sekali lewat untuk ajang iklan atau pencitraan perusahaan. Hasil penelitian menunjukan bahwa CSR di Indonesia masih sekadar basa basi untuk memenuhi legalitas formal. Dari 209 
atau 55,73\% perusahaan yang melakukan kegiatan CSR programnya adalah sumbangan pada lembaga agama (50 perusahaan),sumbangan pada yayasan sosial (39 perusahaan), dan pengembangan komunitas (4 perusahaan) (Wiwik Patiwi, 2012:462). Hasil penelitian menunjukkan pula bahwa CSR tidak mengarah pada filosofi CSR mewujudkan pembangunan berkelanjutan yang mengintegrasikan 3P yaitu people, planet and profit. Negara tidak ikut terlibat dalam program CSR juga tidak ada pengawasan. Apabila yang terjadi adalah semacam ini Negara hanya membuat aturan yang memaksa perusahaan menganggarkan untuk dana social atau sumbangan kepada masyarakat miskin di sekitar lokasi maka benar telah terjadi upaya pengalihan tanggung jawab ekosob kepada perusahaan. Hal ini tidak dibenarkan oleh hukum HAM internasional karena Negara adalah the primary duty bearer, tidak dibenarkan mengalihkan tanggung jawab hak ekosobnya dengan alasan apapaun kepada perusahaan yang sesungguhnya hanya memiliki tanggung jawab untuk menghormati hak ekosob.

\section{Simpulan}

Penormaan TJSL/CSR sebagai suatu kewajiban yang disertai sanksi dalam perundangundangan Indonesia sah dilakukan meskipun penormaan berbeda dengan praktek di Negara lain yang menormakannya sebagaisesuatu yang sifatnya sukarela (voluntary). Sebagai Negara yang berdaulat Indonesia memiliki kewennagan untuk membuat aturan yang berlaku di wilayah Indonesia. Argument hukum yang menjadi landasan adalah karena masalah sosial dan lingkungan yang diakibatkan aktifitas perusahaan sudah sedemikian besarnya di Indonesia, Kesadaran tentang pentingnya CSR juga belum tumbuh sebagaimana di Negara lain sehingga bila dinormakan sebagai sesuatu yang sukarela tidak akan efektif, pengalaman menunjukkan perusahaan bisa melakukan pelanggaran HAM yang sama atau bahkan lebih berat dari yang dilakukan subyek hukum lain. Satu catatan penting bahwa .penormaan CSR sebagai suatu kewjaiban disertai sanksi tidak akan menghilangkan karakteristiknya sebagai social responsibility karena hukum tidak bisa dipisahkan dari social dan moral. Penormaan yang berbeda dengan praktek di Negara lain tidaklah harus dipandang sebagai sesuatu yang buruk atau melanggar hukum. Bisa jadi penormaan seperti yang ada di Indonesia merupakan suatu terobosan baru yang memilki nilai positif yang muncul akibat kebutuhan karena praktek yang lama tidak 
memenuhi kebutuhan lagi. Praktek yang dilakukan Indoensia yangs emula diandang anomaly bisa menjadi praktek hukum yang baru yang diterima masyarakat internasional. Hal ini Nampak dari semakin menguatnya wacana mengubah CSR dari voluntary manjadi mandatory di tingkat internasional.

Penormaan CSR sebagai suatu kewajiban yang disertai sanksi sebagaimana yang ada dalam perundang-undangan Indonesia merupakan wujud keseriusan pemerintah Indonesia melaksanakan kewajibannya sebagai the primary duty bearer melalui penglegislasian, bukan merupakan bentuk pengalihan tanggung jawab ekosob Negara kepada perusahaan yang berkedok CSR asalkan Negara tidak bersikap pasif hanya mengatur dan menerapkan sanksi saja dan lepas tangan sama sekali terhadap program CSR. Negara harus tetap melaksanakan fungsinya sebagai regulator, koordinator sekaligus melakukan fungsi pengawasan. Negara tetap menganggarkan dana pemenuhan ekosob, memfasilitasi, memberikan reward atau insentif kepada perusahaan untuk terwujudnya program CSR yang dapat memeprcepat terwujudnya pembangunan berkelanjutan, mengintegrasikan lingkungan, ekonomi, dan social (masyarakat).Negara harus memiliki metode dan stategi yang jitu agar CSR tidak memberatkan perusahaan tetapi bisa memberikan manfaat sebesar-besarnya kepada semua stakeholder. Apabila kondisi tersebut tidak dipenuhi Negara membiarkan perusahaan berjalan sendiri dengan CSRnya, Negara hanya mewajibkan perusahaan memberikan berbagai sumbangan kepada masyarakat miskin di sekitar operasional perusahaan, menonton dan memberikan sanksi kepada yang tidak melaksanakan maka benar regulasi semacam ini merupakan bentuk pengalihan tanggung jawab ekosob Negara kepada perusahaan yang dikemas atas nama CSR. Artinya negara telah melakukan pelanggaran terhadap hukum HAM internasional mengingat negara adalah the primary duty bearer, memiliki kewajiban memenuhi, melindungi, menghormati dan memajukan hak ekosob sekalipun secara bertahap. Negara dilarang mengalihkan tanggung jawabnya kepada perusahaan dengan alasan apapaun termasuk ketidakmampuan ekonomi mengingat tanggung jawab perusahaan hanya sebatas menghormati HAM. 


\section{Daftar Pustaka}

Adi Prasetyo,Yosep. 2012. “Hak Ekosob dan Kewajiban negara’, presented on Pemerkuatan pemahaman HAM untuk hakim Seluruh Indonesia, as held by PUSHAM UII in collaboration with Komisi tdisial Indonesia and Norwegian Centre for Human Right, Lombok, 28 - 31 Mei 2012

Giri Ahmad Taufik. “Hak Asasi Manusia Dan Tanggung Jawab Sosial Perusahaan”, last visited on 3 March 2014 available at http://bandungfreeschool.wordpress.com/2008/11/29/hakasasi-manusia-dan-tanggung-jawab-sosial-perusahaan/

Aguirre, Daniel. 2011. Corporate Liability for Economic, Social and Cultural Rights Revisited; The Failure of International Cooperation, 42 Cal. W. Int'l L.J. 123

Hasan Asy’ari. 2009. Implementasi CSR sebagai Modal Sosial pada PT Newmont”, thesis on Master of Law, post graduate of Law faculty, University of Diponegoro

Bantekas, Ilias, 2004, “Corporote Social Responsibility in International Law”, in 22 B.U. Int'l L.J. 309

Buhman, Karin, “Corporate Social responsibility and Business Responsibilities for Human Rights, Nordisk Tidsskrift for Menneskerettigheter, VOL. 25, Nr 4, p.337

Davidsson,Pall A. , 2002, Legal Enforcement of Corporate Social Respnsibility within the EU, on 8 Colum. J. Eur. L. 529

Christian Dony Putranto (translator). 2012. Prinsip-prinsip panduan untuk bisnis dan HAM, kerangka PBB “Perlindungan, Penghormatan dan Pemulihan”. Jakarta : ELSAM.. p. vii. The said princliples as stated in this gudaince is also named Ruggie principle, taken from the name of John Ruggie, Committee chairman which appointed by UN to formulate human rights for business

ELSAM. 2012. Prinsip-Prinsip Panduan untuk Bisnis dan HAM Kerangka PBB "Perlindungan, penghormatan, dan Pemulihan”,

Harper Ho, Virginia. 2013. "Beyond regulation: A Comparative Look at State-Centric Corporate social responsibility and The Law in China”, 46 Vand. J. Transnat'l L. 375

R Herlambang Perdana. "Strategi Pemenuhan hak Ekosob di Jatim, acessed on 3 March 2014 http://kompas.com/kompas-cetak/0602/21/jatim/49849.htm

Arifin Imamul. 2011. Fungsi dan peran pemerintah dibidang ekonomi, accessed in www.artikelekonomi.net. on 2 January 2014 
K, Bertens. 2000. Pengantar Etika Bisnis, Kanisius. Yogyakarta

Kiroyan, Noke, 2007, “Corporate Sosial Responsibility and The Indonesian Mining Industry”, article which was presented on Indonesian Mining Conference and Exhibition

T. Gayus Lumbuun. “Telaah Hukum atas ketentuan Corporate Sosial responsibility dalam UU PT (Sebuah Kajian dari perspektif Etika Bisnis ke Pertanggungjawaban Hukum”), last visited on 23 January 2014 at http://supremasihukumusahid.org/attachments/article/79/\%5BFull\%5D\%20Telaah\%20H ukum\%20Atas\%20Ketentuan\%20Corporate\%20Social\%20Responsibility\%20Dalam\%20 Uupt\%20\%20Prof.\%20Dr.\%20T.\%20Gayus\%20Lumbuun,\%20S.H.,\%20M.H..pdf

Mares, Radu, 2010, A gap in the corporate responsibility to respect human rights, Monash University Law Review, vol. 36.3 .

McClintock, Brent. 1999. 'The Multinational Corporation and Social Justice: Experiments in Supranational Governance', Review of Social Economy, Vol. LVII, No. 4

No name, “Mempermasalahkan lagi CSR”, diakses 9 pebruary 2014 di http://www.hukumonline.com/berita/baca/lt4cbf5a4325dfd/mempermasalahkan-lagitanggung-jawab-sosial-perusahaan

No name, http://www.hukumonline.com/berita/baca/lt4d000f3828437/pemenuhan-hak-ekosobbukan-semata-tanggung-jawab-negara

Wiwik Pratiwi. 2012. "Tanggung Jawab Sosial perusahaan Berdimensi HAM dan Implikasinya dalam Meningkatkan Iklim Investasi di Indonesia”. in Pusham UII. 2012. To Fulfill and To Protect: Membaca Kasus-Kasus Aktual tentang Hak Asasi Manusia, PUSHAM UII in collaboration with Norwegian Center for Human Rights (NCHR) Universitas Oslo, Norwegia, Yogyakarta, First Edition

Rahayu. "Kewajiban Negara Indonesia Mengimplementasikan Kovenan Hak Ekonomi, dan Sosial, Budaya" paper presented on "Semiloka Agenda Strategis Penelitian dan Pengembangan Lintas Sektoral di Bidang Hak Asasi Manusia dalam Perspektif Hak Hak Ekonomi, Sosial dan Budaya” held by Research and development department, law and Human Right ministerial of republic of Indonesia, in collaboration with la w and Human Right ministerial, cenre of Java Region, on Monday, 12 July 2010 
Moh Rivai Anwar, M. Yunus Wahid, Abrar Saleng. "Fungsi Negara dalam Pelaksanaan Tanggung Jawab Sosial perusahaan, accessed on 20 February 2014 in http://pasca.unhas.ac.id/jurnal/files/987dc6e9430c90fada5dd0c7f90beb5f.pdf

Sefriani. 2007. “Tanggung Jawab Perusahaan Transnasional Terhadap Pelanggaran HAM Dalam Perspektif Hukum Internasional”, in journal of UNISIA, UII, No 65, Vol XXX.

A Sony Keraf. 1998. Etika Bisnis (Tuntutan dan Relevansinya). Yogyakarta : Kanisius.

Sukarmi, "Tanggung Jawab Sosial Perusahaan (Corporate social Responsibility) dan Iklim Penanaman Modal, dalam Hukum Bisnis”, media publikasi peraturan perundangundangan dan informasi hukum,12 February 2014, Kementrian hukum dan HAM, last visited on 23 january 2014 in http://ditjenpp.kemenkumham.go.id/hukum-bisnis/84tanggung-jawab-sosial-perusahaan-corporate-social-responsibility-dan-iklimpenanaman-modal.html

Sumantoro. 1984. Bunga Rampai Permasalahan Penanaman Modal dan Pasar Modal/ Problems of Investment in Equities and in Securities, Binacipta.

AB Susanto. 2007. A Strategic Management Approach, CSR, The Jakarta Consulting Group, Jakarta.

Thirarungrueang, Kunnawee. 2013. "Rethinking CSR in Australia: time fo binding regulation”, Int.J.L.M. 2013, 55(3), 173-200

\section{Document:}

Constitutional Court sentence of Republic of Indonesia, Number 53/PUU-VI/2008

General Comment No. 3/1990 alinea 10, Monitoring Committee of ESCR stated that "minimum core obligation" refers to state responsibility to fulfil minimum people's needs on ESCR

Maastricht Guidelines on Violations of Economic, Social and Cultural Rights

OECD Principles of Corporate Governance Principle 